\title{
Production Potential and Soil Fertility Status of Ratoon Sugarcane (Saccharum officinarum L.) as Influenced by Time and Level of Earthing Up and Nitrogen Levels in North-Eastern Uttar Pradesh, India
}

\author{
C. M. Dev ${ }^{1}$, R. K. Singh ${ }^{2}$, R. N. Meena ${ }^{2}$, Ashok Kumar ${ }^{2} \&$ Kanchan Singh $^{2}$ \\ ${ }^{1}$ Department of Agronomy, SG CARS, Jagdalpur, Bastar, Chhattisgarh-494005, India \\ ${ }^{2}$ Department of Agronomy, I. A.S., Banaras Hindu University, Varanasi, Uttar Pradesh-22005, India \\ Correspondence: C. M. Dev, Department of Agronomy, SG CARS, Jagdalpur, Bastar, Chhattisgarh-494005, India. \\ E-mail: agrodev1971@gmail.com
}

Received: May 21, 2012 Accepted: October 28, 2012 Online Published: November 20, 2012

doi:10.5539/sar.v2n1p143 URL: http://dx.doi.org/10.5539/sar.v2n1p143

\begin{abstract}
A field experiment was carried out during the spring seasons of 2008-09 and 2009-10 at Varanasi, Uttar Pradesh to find out exact time of earthing up with level of earthing up and optimum doses of nitrogen for getting higher productivity, monetary returns, and changes in the fertility status of soils after harvest of ratoon sugarcane (Saccharum officinarum L.). Twentieth fifth April earthed crop produced significantly more height of tillers, leaf area index at maximum tillering stage, grand growth stage and at harvest, dry matter/tiller at maximum tillering stage at grand growth stage and at harvest, cane length, cane diameter of top, middle and bottom, weight of cane, cane yield, monetary returns, $\mathrm{B} / \mathrm{C}$ ratio, $\mathrm{N}, \mathrm{P}$ and $\mathrm{K}$ uptake except number of tillers/ha, number of millable cane/ha and net available soil nutrient after the harvest of ratoon crops as compared to $25^{\text {th }}$ May and $25^{\text {th }}$ June respectively. Twentieth $\mathrm{cm}$ height of earthing up from the ridge also significantly increased all the above parameters such as height of tillers, LAI of maximum tillering stage, grand growth stage and harvest, dry matter/tiller at maximum tillering stage, grand growth stage and at harvest, cane length, weight of cane and cane yield than that of $10 \mathrm{~cm}$ earthed crop in both the ratoon crops. Application of $210 \mathrm{~kg} \mathrm{~N} / \mathrm{ha}$ linearly and significantly increased number of tillers/ha at 60 and 120 days after ratooning, height of tillers at 120 days after ratooning, LAI at maximum tillering stage, grand growth stage, and at harvest, dry matter/tiller at maximum tillering stage, grand growth stage and at harvest, number of millable cane, cane length, cane weight, cane yield, monetary returns, B/C ratio and N, P, K uptake followed by $180 \mathrm{~kg} \mathrm{~N} / \mathrm{ha}$. Ratoon crop showed that there was a build up of nitrogen and phosphorous but depletion in potassium content of the soil. $210 \mathrm{~kg} \mathrm{~N} / \mathrm{ha}$ with earlier earthed at $25^{\text {th }}$ April to a level of $20 \mathrm{~cm}$ was found optimum for obtaining higher yields and monetary returns.
\end{abstract}

Keywords: earthing up, economics, nitrogen, soil fertility, ratoon sugarcane

\section{Introduction}

Sugarcane (Saccharum officinarum) is an important agricultural commercial cash crop and also unique in the sense that a number of succeeding cane crops are raised from a single planting which is an integral component of sugarcane production system. In India more than 50 to $55 \%$ of sugarcane acreage is occupied by ratoons, which are often poorer yielders than the plant cane due to non adoption of improved agricultural technologies. Thus, even a small improvement in ratoon crop would add considerably to overall sugarcane production and productivity in the country. It will as well benefit cane growers by vacating the fields earlier for sowing of wheat and other rabi crops timely, as well as mill owner's by providing mature cane earlier in the crushing period. In this way, ratoon crop often gives better yield, quality and sugar recovery than plant cane.

Abundant tillering in ratoon crop is a desired inheritance character but all tillers are not productive with proper amount of juice. In order to reduce the number of excessive tillers and converting them into millable canes, earthing up plays important role in maintaining the growth, yield, and juice quality of the sugarcane plant as well as for ratoon. Besides, it has added advantages in terms of pruning/cutting of old roots, moisture conservation, addition of organic matter, enhanced availability and uptake of plant nutrients, efficient utilization of solar 
radiation, suppression of weeds, and preventing canes from lodging (Yadav \& Shukla, 2008). Sugarcanes as well as ratoons are highly exhaustive crops having higher demand for nitrogenous fertilizer because of shallow root system, decaying of old roots, sprouting of stubble buds, and immobilization of nitrogen (Lal \& Singh, 2008). It is, therefore, to use $20-25$ per cent more nitrogenous fertilizer over $150 \mathrm{~kg} \mathrm{~N} / \mathrm{ha}$ (recommended dose of nitrogen for ratoon crop). In general, nitrogen reduced the number of unwanted tillers and brought into constant number of millable canes/ha. The works on time and level of earthing up and nitrogen levels on sugarcane ratoon crop is very meager in Gangetic alluvial (sandy loam) soils of Eastern Uttar Pradesh. Hence, there is a lot of scope to exploit the potential of sugarcane ratoon crop grown under above conditions. Considering the above facts into consideration this experiment was designed to test the ratoon sugarcane with different time and level of earthing up along with different levels of nitrogen fertilizers for higher growth, yield, economics and changes in soil fertility status of Indo-Gangetic alluvial soils of Uttar Pradesh.

\section{Materials and Methods}

The field experiment was carried out during spring seasons of 2008-09 and 2009-10 at Research Farm, Institute of Agricultural Sciences, Banaras Hindu University, Varanasi, (U.P.). The experimental soil was sandy clay loam with pH 7.94, with organic carbon $0.33 \%$, low available $\mathrm{N}(185.62 \mathrm{~kg} / \mathrm{ha})$, low available $\mathrm{P}(24.45 \mathrm{~kg} / \mathrm{ha})$ and medium available K $(235.37 \mathrm{~kg} / \mathrm{ha})$. Eighteen treatments combining of 3 dates of earthing up i.e., on $25^{\text {th }}$ April, $25^{\text {th }}$ May and $25^{\text {th }}$ June with two levels (i.e., $10 \mathrm{~cm}$ height and $20 \mathrm{~cm}$ height) of earthing up were assigned in main plots and three nitrogen levels (viz. 150, 180 and $210 \mathrm{~kg} \mathrm{~N} / \mathrm{ha}$ ) were randomly assigned in sub plots in a split plot design and replicated thrice. The cane plantation was already installed with a row spacing of $90 \mathrm{~cm}$ in the experimental field. The crop was harvested and the plantation was irrigated with flooding system of irrigation. After one or two days of irrigation, in order to accommodate experimental design, stubbles of fifth rows were uprooted to make irrigation channels as well as boundary wall for the experimental plots. Similarly, stubbles from the rows of sugarcane plants were also uprooted after a measured length of a plot size so as to separate one plot to another. Thus, all the uprooted stubbles of canes were shifted to vacant places (gap filling) so as to get desired plant population to optimize the yields of ratoon sugarcane. Full dose of phosphorous (through Single Super Phosphate) at the rate of $80 \mathrm{~kg} \mathrm{P}_{2} \mathrm{O}_{5} / \mathrm{ha}$, potassium (muriate of potash) at the rate of $80 \mathrm{~kg} \mathrm{~K}_{2} \mathrm{O} / \mathrm{ha}$ and one third of nitrogen as per treatment were applied at the time of ratooning. Rest two third of nitrogen in the form of urea was top dressed in two equal splits before earthing up in the month of April and May as per treatments.

Sugarcane ratoon crops were harvested after the completion of 12 month i.e., $15^{\text {th }}$ February or March. Various growth parameters viz. number of tillers/ha, height of tillers, LAI, dry matter accumulation and number of millable canes were recorded at standing crop. Similarly yield and yield attributes like cane length, cane diameter, cane weight and cane yield were noted after the harvest of ratoon crop. Economic analysis was done based on the prevailing market price of the inputs and produce i.e. fertilizer nitrogen at the rate of Rs $11.30 / \mathrm{kg}$, phosphorous at the rate of Rs $21.25 / \mathrm{kg}$, potassium at the rate of Rs $8.00 / \mathrm{kg}$ and cost of sugarcane at the rate of Rs 2932.50/t (Sugarcane Corporation of India) during 2009-10, its rate was Rs 293.25/quintal). The plant cane, green leaves and trashes were analysed to compute uptake of nutrients (N, P, and, K) by the plants. Soil samples $(0-22.5 \mathrm{~cm})$ were collected before start of ratooning and after harvest of ratoon crop used to determine $\mathrm{pH}$ by using glass Electrode $\mathrm{pH}$ meter (Jackson, 1973), EC through Electrical conductivity Meter method (Jackson, 1973), organic C by Wet chromic acid digestion method (Walkely \& Black, 1934), available N with the help of Alkaline Potassium Permanganate Method (Subbiah \& Asija, 1956), P by Olsen's method (Olsen et al., 1954), and K through Flame Photometer (Ammonium acetate extract) (Jackson, 1973).

\section{Results and Discussion}

\subsection{Numbers of Tillers and Number of Millable Canes}

Results obtained from the ratoon crops of sugarcane showed that earthing up at $25^{\text {th }}$ June being compared with $25^{\text {th }}$ May and $25^{\text {th }}$ April significantly enhanced the number of tillers but did not affect the number of millable canes/ha. The per cent increase in number of tillers/ha due to late earthing up was $17.37 \%$ at 60 DAR and $16.32 \%$ at 120 DAR. These might be due to the fact that earlier earthing up provides proper soil moistures, higher soil volumes for root proliferation and earlier reduction of excessive tillers which minimize the competition for nutrient and soil aeration and converting the existing numbers into millable canes by utilizing nutrients and soil moisture and by checking aeration in new emerging buds and late tillering. Earlier the earthed up, greater is its effect on deduction of excessive tillers and the same was found by Singh et al. 2008. Increasing the nitrogen levels from 150 to $210 \mathrm{~kg} \mathrm{~N} / \mathrm{ha}$ with June and May earthing also increased the number of tillers by avoiding the compactness of soil, proliferating the more tillers to grow ultimately resulted in higher number of millable canes but may not be productive. Shukla, 2005 also recorded highest number of tillers/ha with $200 \mathrm{Kg}$ 
$\mathrm{N} / \mathrm{ha}$ in spring season. It is cleared from the Table 1 that numbers of millable canes were not affected by the time and level of earthing up. However, $20 \mathrm{~cm}$ height of earthing significantly recorded lower number of tillers/ha whereas $210 \mathrm{~kg} \mathrm{~N} / \mathrm{ha}$ exhibited highest number of tillers and millable cane/ha at 60 and 120 days after ratooning whereas Lal et al. 2008 observed that significant increase in the production of tillers and millable canes due to increasing nitrogen doses from $75 \%$ to $100 \%$ of recommendation.

Table 1. Number of tillers/ha, height of tillers $(\mathrm{cm})$, leaf area index (\%), dry matter/tiller $(\mathrm{g})$, number of millable canes/ha and cane length $(\mathrm{cm})$ of ratoon sugarcane as influenced by time and level of earthing up and nitrogen levels

\begin{tabular}{|c|c|c|c|c|c|c|c|c|c|c|c|}
\hline \multirow{2}{*}{ Treatment } & \multicolumn{2}{|c|}{$\begin{array}{l}\text { Number of } \\
\text { tillers/ha } \\
\text { ('ooo/ha) }\end{array}$} & \multirow{2}{*}{$\begin{array}{c}\text { Height of } \\
\text { tillers } \\
(\mathrm{cm}) \text { at } \\
120 \\
\text { DAR }\end{array}$} & \multicolumn{3}{|c|}{ Leaf area index } & \multicolumn{3}{|c|}{ Dry matter/tiller (g) } & \multirow{2}{*}{$\begin{array}{l}\text { No.of } \\
\text { millable } \\
\text { canes/ha }\end{array}$} & \multirow{2}{*}{$\begin{array}{c}\text { Cane } \\
\text { length } \\
(\mathrm{cm})\end{array}$} \\
\hline & $\begin{array}{l}60 \\
\text { DAR }\end{array}$ & $\begin{array}{l}120 \\
\text { DAR }\end{array}$ & & $\begin{array}{l}\text { Max. } \\
\text { tillering } \\
\text { stage }\end{array}$ & $\begin{array}{l}\text { Grand } \\
\text { growth } \\
\text { stage }\end{array}$ & Harvest & $\begin{array}{l}\text { Max. } \\
\text { Tillering } \\
\text { stage }\end{array}$ & $\begin{array}{l}\text { Grand } \\
\text { growth } \\
\text { stage }\end{array}$ & Harvest & & \\
\hline \multicolumn{12}{|c|}{ Time of earthing up } \\
\hline $\mathrm{M}_{1}-25^{\mathrm{th}}$ April & 197.9 & 105.1 & 171.8 & 4.1 & 6.8 & 6 & 72.8 & 77.3 & 508.8 & 103.1 & 399.5 \\
\hline $\mathrm{M}_{3}-25^{\text {th }}$ June & 239.5 & 125.7 & 152.3 & 3.6 & 5.7 & 4.9 & 59.1 & 65.7 & 377.4 & 111.1 & 376.3 \\
\hline $\mathrm{SEm} \pm$ & 3.32 & 1.9 & 1.5 & 0.1 & 0.1 & 0.1 & 0.8 & 2.1 & 7.1 & 2.6 & 3.4 \\
\hline $\mathrm{CD}(\mathrm{P}=0.05)$ & 10.5 & 5.9 & 4.6 & 0.2 & 0.3 & 0.4 & 2.4 & 6.5 & 22.4 & NS & 10.8 \\
\hline \multicolumn{12}{|c|}{ Level of earthing up } \\
\hline $\begin{array}{l}\mathrm{L}_{1} \text { - Light }(10 \mathrm{~cm} \\
\text { height })\end{array}$ & 230.8 & 122.3 & 157.4 & 3.6 & 5.9 & 5.1 & 63.2 & 68.6 & 410.7 & 110.8 & 376.9 \\
\hline $\begin{array}{l}\mathrm{L}_{1} \text { - Light }(20 \mathrm{~cm} \\
\text { height })\end{array}$ & 212.0 & 109.7 & 165.6 & 4.0 & 6.4 & 5.6 & 67.3 & 75.4 & 456.5 & 105.3 & 392.6 \\
\hline $\operatorname{SEm} \pm$ & 2.7 & 1.5 & 1.2 & 0.1 & 0.1 & 0.1 & 0.6 & 1.7 & 5.8 & 2.1 & 2.8 \\
\hline $\mathrm{CD}(\mathrm{P}=0.05)$ & 8.5 & 4.8 & 3.7 & 0.2 & 0.2 & 0.3 & 1.9 & 5.3 & 18.3 & NS & 8.8 \\
\hline \multicolumn{12}{|c|}{ Nitrogen levels (kg/ha) } \\
\hline$N-150$ & 209.3 & 97.4 & 139.9 & 3.5 & 5.5 & 4.8 & 57.1 & 64.8 & 371.1 & 103.1 & 360.2 \\
\hline $\mathrm{N}_{2}-180$ & 223.6 & 120.3 & 165.4 & 3.9 & 6.4 & 5.5 & 67.1 & 74.2 & 461.0 & 109.9 & 396.9 \\
\hline$N_{3}-210$ & 231.3 & 130.2 & 179.3 & 4.1 & 6.6 & 5.9 & 71.5 & 77.1 & 469 & 111.1 & 397.1 \\
\hline $\mathrm{SEm} \pm$ & 1.9 & 1.3 & 0.5 & 0.1 & 0.1 & 0.1 & 0.3 & 1.1 & 5.8 & 1 & 2.6 \\
\hline $\mathrm{CD}(\mathrm{P}=0.05)$ & 5.5 & 3.9 & 1.4 & 0.2 & 0.2 & 0.2 & 0.9 & 3.3 & 17 & $2.9 \mathrm{~S}$ & 7.5 \\
\hline
\end{tabular}

\subsection{Growth Attributes of Ratoon Sugarcane}

Earlier earthed crop recorded significantly higher plant height, leaf area index, dry matter/tiller Table (1) and increased plant height which was mainly due to availed conducive soil temperature and soil environment during the period of grand growth stage, the growth was sudden accelerated. Higher dry matter accumulation of the crop was a result of higher LAI increased due levels of nitrogen fertilizer as Ali et al. 2002 reported that significantly higher dry matter accumulation was also obtained at higher fertilizer levels than lower levels and control. Twentieth $\mathrm{cm}$ height of earthing up recorded comparatively higher dry matter and LAI as compared to $10 \mathrm{~cm}$ height of earthing. Height of tillers at 120 DAR, increased LAI up to grand growth stage and slightly lowered at harvest, dry matter/tiller at harvest as compared to the lower levels of nitrogen doses $(180 \mathrm{~kg} \mathrm{~N} / \mathrm{ha})$ and least at $150 \mathrm{~kg} \mathrm{~N} / \mathrm{ha}$ (control). These parameters were increased by $22.00 \%, 15.81 \%, 19.35 \%, 10.52,19.17 \%, 20.12 \%$, $16.01 \%$, and $20.81 \%$ in pooled data ratoon crops of both years respectively. These findings are similar with those of Lal and Singh (2008).

\subsection{Cane Length, Diameter and Cane Weight and Cane Yield}

The data (Table 1 and 2) indicated that the April earthed crop recorded significantly higher cane length, cane diameter of top, middle and bottom, cane weight, and cane yield as compared to the late earthed crop in both first and second ratoon which might be due to earlier earthed crop experienced comparatively longer time period for reducing excessive tillers, soil volume for well growth of roots and shoots, availability of soil moisture, nutrients and less competition between the plants fetched higher cane length, cane diameter, cane weight, and cane yield. Delaying the earthing up produced significant reduction in the values of yield attributes resulting in lower yields 
of cane whereas Qadir et al. 1998 found that the yield progressively decreased as earthing up was delayed. Level of earthing up also significantly recorded higher cane length, cane diameter of bottom, middle and top, weight of cane as well as cane yield because heavy earthed up crop to a height of $20 \mathrm{~cm}$ produced higher soil volume availed the proper growth environment for the crops providing constant soil moisture, aeration and high anchorage for sugarcane to prevent from lodging which ultimately increased the cane yield for which deep earthing up found most effective than the shallow or light earthing up. Similar findings were reported by Dougall and Halpin (2008). Application of nitrogen at $210 \mathrm{~kg} / \mathrm{ha}$ increased the cane length by $9.30 \%$, weight of cane by $19.41 \%$, and cane yield by $23.56 \%$ as compared to $150 \mathrm{~kg} \mathrm{~N} / \mathrm{ha}$. The table showed that there was a constant increase in all the yield attributes with each increment of nitrogen levels during both the years of investigation. Increased values (Table 1 and 2) were due to significant translocation and storage of photosynthates from source to sink resulted significant improvement in almost all the yield attributing characters with the corresponding increase in nitrogen use efficiencies with increased nitrogen levels. Similar findings were reported by Choudhary and Ullah (2001).

Table 2. Cane diameter $(\mathrm{cm})$, cane weight $(\mathrm{g})$, cane yield $(\mathrm{t} / \mathrm{ha})$ and economics of ratoon sugarcane as influenced by time and level of earthing up and nitrogen levels

\begin{tabular}{|c|c|c|c|c|c|c|c|c|c|}
\hline \multirow[t]{2}{*}{ Treatment } & \multicolumn{3}{|c|}{ Cane diameter $(\mathrm{cm})$} & \multirow{2}{*}{$\begin{array}{c}\text { Cane } \\
\text { weight } \\
(\mathrm{g})\end{array}$} & \multirow{2}{*}{$\begin{array}{l}\text { Cane } \\
\text { yield } \\
(\mathrm{t} / \mathrm{ha})\end{array}$} & \multirow{2}{*}{$\begin{array}{c}\text { Gross } \\
\text { Return } \\
\text { (Rs/ha) }\end{array}$} & \multirow{2}{*}{$\begin{array}{l}\text { Total cost } \\
\text { of } \\
\text { cultivation } \\
\text { (Rs/ha) }\end{array}$} & \multirow{2}{*}{$\begin{array}{c}\text { Net } \\
\text { Return } \\
\text { (Rs/ha) }\end{array}$} & \multirow{2}{*}{$\begin{array}{l}\text { B: } \mathrm{C} \\
\text { ratio }\end{array}$} \\
\hline & $\begin{array}{l}\text { Top of } \\
\text { cane }\end{array}$ & $\begin{array}{l}\text { Middle } \\
\text { of cane }\end{array}$ & $\begin{array}{l}\text { Bottom } \\
\text { of cane }\end{array}$ & & & & & & \\
\hline \multicolumn{10}{|c|}{ Time of earthing up } \\
\hline $\begin{array}{l}\mathrm{M}_{1}-25^{\text {th }} \\
\text { April }\end{array}$ & 2.4 & 2.6 & 2.7 & 1459.7 & 158.8 & 465779 & 133588 & 270389 & 3.5 \\
\hline $\mathrm{M}_{2}-25^{\mathrm{th}}$ May & 2.3 & 2.4 & 2.5 & 1311.8 & 145.2 & 425864 & 133588 & 241634 & 3.2 \\
\hline $\begin{array}{l}\mathrm{M}_{3}-25^{\text {th }} \\
\text { June }\end{array}$ & 2.3 & 2.4 & 2.5 & 1252.5 & 139.2 & 408269 & 133588 & 236646 & 3.1 \\
\hline $\operatorname{SEm} \pm$ & 0.03 & 0.03 & 0.03 & 11.6 & 1.7 & - & - & - & - \\
\hline $\mathrm{CD}(\mathrm{P}=0.05)$ & 0.08 & 0.09 & 0.1 & 36.4 & 5.3 & - & - & - & - \\
\hline \multicolumn{10}{|c|}{ Level of earthing up } \\
\hline $\begin{array}{l}\mathrm{L}_{1}-\text { Light } \\
(10 \mathrm{~cm} \\
\text { height })\end{array}$ & 2.3 & 2.4 & 2.5 & 1301 & 143.3 & 420108 & 132808 & 233405 & 3.2 \\
\hline $\begin{array}{l}\mathrm{L}_{2}-\text { Heavy } \\
(20 \mathrm{~cm} \\
\text { height) }\end{array}$ & 2.4 & 2.5 & 2.6 & 1381.7 & 152.3 & 446500 & 134368 & 265707 & 3.3 \\
\hline $\mathrm{SEm} \pm$ & 0.02 & 0.02 & 0.03 & 9.4 & 1.4 & - & - & - & - \\
\hline $\mathrm{CD}(\mathrm{P}=0.05)$ & 0.07 & 0.07 & 0.08 & 29.7 & 4.3 & - & - & - & - \\
\hline \multicolumn{10}{|c|}{ Nitrogen levels (kg/ha) } \\
\hline$N_{1}-150$ & 2.2 & 2.3 & 2.4 & 1182.1 & 124.9 & 366237 & 133079 & 171267 & 2.8 \\
\hline $\mathrm{N}_{2}-180$ & 2.4 & 2.5 & 2.6 & 1375.1 & 155 & 454619 & 133588 & 251008 & 3.4 \\
\hline$N_{3}-210$ & 2.5 & 2.5 & 2.7 & 1466.8 & 163.4 & 479056 & 134096 & 326393 & 3.6 \\
\hline $\operatorname{SEm} \pm$ & 0.01 & 0.02 & 0.02 & 4.7 & 0.8 & - & - & - & - \\
\hline $\mathrm{CD}(\mathrm{P}=0.05)$ & 0.03 & 0.06 & 0.07 & 13.7 & $2.3 \mathrm{~S}$ & - & - & - & - \\
\hline
\end{tabular}

\subsection{Nutrient Uptake by Sugarcane Plant}

Earthing up on $25^{\text {th }}$ April (Table 3) recorded significantly higher N, P and K uptake with 24.22, 18.44 and 18.29 per cent respectively was highly comparable with that of $25^{\text {th }}$ May and $25^{\text {th }}$ June. Higher the yield $(158.8 \mathrm{t} / \mathrm{ha})$, more would be the uptake of nutrients which was due to proper growth and development by providing more soil volume for root proliferation as results were reported by Singh et al. 2008. Level of earthing up with $20 \mathrm{~cm}$ height also recorded comparatively higher $\mathrm{N}, \mathrm{P}$, and $\mathrm{K}$ uptake $7.40 \%, 11.24 \%$, and $7.39 \%$ respectively in ratoon crops. Highest N, P, and K uptake (Table 3) was obtained under $210 \mathrm{~kg} \mathrm{~N} / \mathrm{ha} \mathrm{(19.00),} \mathrm{(18.82)} \mathrm{and} \mathrm{(19.61)} \mathrm{per}$ cent respectively followed by $180 \mathrm{~kg} \mathrm{~N} / \mathrm{ha}$ (15.71), (13.21) and (15.66) and over control (150 kg N/ha) because higher $\mathrm{N}$ rates also increases the uptake of $\mathrm{P}$ and $\mathrm{K}$ resulted in higher cane yield. These results are in conformity with the findings of Ashraf et al. (2008). Different treatments have brought about significant changes in status of 
available soil N, P, and K. Maximum available N, P, and K were recorded when crop was earthed in June followed by May. Due to different level of earthing up, available $\mathrm{N}$ and $\mathrm{P}$ status of the soil varied and was significantly higher with $10 \mathrm{~cm}$ height of earthing up from the ridge which was $4.17,1.05$ and $12.00 \%$ more than that of $20 \mathrm{~cm}$ height of earthing up from the ridge. $210 \mathrm{~kg} \mathrm{~N} / \mathrm{ha}$ significantly influenced on build up of $\mathrm{N}$ over the initial status of the soil from 184.0 to $212.89 \mathrm{~kg} / \mathrm{ha}$ with an increase in $49.34 \%$ (210 kg N/ha) followed by $31.36 \%$ (150 kg N/ha) as compared to $180 \mathrm{~kg} \mathrm{~N} / \mathrm{ha}$. There was higher build up of $\mathrm{P}$ in the soil was recorded by $29.46 \%$ under $150 \mathrm{~kg} \mathrm{~N} / \mathrm{ha}$ followed by $12.12 \% \mathrm{P}$ build up was observed with $180 \mathrm{~kg} \mathrm{~N} / \mathrm{ha}$ possibly because of comparatively higher uptake of $\mathrm{P}$ by the crop at higher level of $\mathrm{N}$ resulted in lower $\mathrm{P}$ build up as compared to lower doses of N duly reported by Shukla (2005). Since sugarcane is highly responsive towards K fertilizers for higher yields due to which there was no build up of $\mathrm{K}$ in the soil instead of depletion of $\mathrm{K}$ over the initial values because of higher $\mathrm{K}$ uptake by the crop favoured by increased doses of $\mathrm{N}$ as compared to the amount of $\mathrm{K}$ applied to the soil for plant growth and development. Similar beneficial effects of levels of nitrogen for higher K uptake were reported by several workers in sugarcane (Shukla, 2005).

Table 3. Total nutrient uptake, net available soil nutrient and nutrient loss or benefit over the initial soil values $(\mathrm{kg} / \mathrm{ha})$ of ratoon sugarcane as influenced by time and level of earthing up and nitrogen levels

\begin{tabular}{|c|c|c|c|c|c|c|c|c|c|}
\hline \multirow[t]{2}{*}{ Treatment } & \multicolumn{3}{|c|}{$\begin{array}{l}\text { Total nutrient uptake } \\
(\mathrm{kg} / \mathrm{ha})\end{array}$} & \multicolumn{3}{|c|}{$\begin{array}{l}\text { Net available soil nutrient } \\
(\mathrm{kg} / \mathrm{ha})\end{array}$} & \multicolumn{3}{|c|}{$\begin{array}{c}\text { Loss }(-) \text { or benefit }(+) \text { over initia } \\
\text { values }(\mathrm{kg} / \mathrm{ha})\end{array}$} \\
\hline & $\mathrm{N}$ & $\mathrm{P}$ & $\mathrm{K}$ & $\mathrm{N}$ & $\mathrm{P}$ & K & $\mathrm{N}$ & $\mathrm{P}$ & $\mathrm{K}$ \\
\hline \multicolumn{10}{|l|}{ Time of earthing up } \\
\hline $\mathrm{M}_{1}-25^{\text {th }}$ April & 275.4 & 36.3 & 315.9 & 209.3 & 96 & 96 & 8.5 & 35.8 & -31 \\
\hline $\mathrm{M}_{2}-25^{\text {th }}$ May & 224.4 & 31.8 & 275.2 & 259.9 & 143.8 & 142.5 & 52.2 & 35.6 & 10.6 \\
\hline $\mathrm{M}_{3}-25^{\text {th }}$ June & 208.7 & 29.6 & 258.1 & 278.8 & 144.5 & 163.7 & 61.6 & 38.2 & 18.4 \\
\hline $\mathrm{SEm} \pm$ & 2.8 & 0.3 & 1.8 & - & - & - & - & - & - \\
\hline $\mathrm{CD}(\mathrm{P}=0.05)$ & 8.9 & 0.9 & 5.5 & - & - & - & - & - & - \\
\hline \multicolumn{10}{|l|}{ Level of earthing up } \\
\hline $\mathrm{L}_{1}$ - Light (10 cm height) & 227.1 & 30.6 & 272.2 & 254.6 & 141.8 & 142.6 & 36.6 & 33.8 & 4.1 \\
\hline $\mathrm{L}_{2}$ - Heavy (20 cm height) & 245.3 & 34.5 & 293.9 & 244 & 140.3 & 125.5 & 39.1 & 39.2 & -5.5 \\
\hline $\mathrm{SEm} \pm$ & 2.3 & 0.2 & 1.4 & - & - & - & - & - & - \\
\hline $\mathrm{CD}(\mathrm{P}=0.05)$ & 7.3 & 0.7 & 4.5 & - & - & - & - & - & - \\
\hline \multicolumn{10}{|l|}{ Nitrogen levels (kg/ha) } \\
\hline $\mathrm{N}_{1}-150$ & 207.1 & 28.9 & 247.6 & 226.6 & 140.9 & 162.9 & 37.3 & 43.7 & 38.4 \\
\hline $\mathrm{N}_{2}-180$ & 245.7 & 33.3 & 293.6 & 244.8 & 142.1 & 128 & 25.6 & 35.1 & -10.5 \\
\hline $\mathrm{N}_{3}-210$ & 255.7 & 35.6 & 308 & 276.6 & 140.1 & 111.2 & 50.6 & 30.8 & -15.7 \\
\hline $\mathrm{SEm} \pm$ & 0.8 & 0.2 & 1.2 & - & - & - & - & - & - \\
\hline $\mathrm{CD}(\mathrm{P}=0.05)$ & 2.4 & 0.6 & 3.6 & - & - & - & - & - & - \\
\hline
\end{tabular}

Analysis of variance showed significant effect of earthing up and $\mathrm{N}$ levels for both net returns and benefit: cost (B: C) ratio. Maximum net monetary returns and B: C ratios were obtained with $25^{\text {th }}$ April earthed crops as compared to $25^{\text {th }}$ May and $25^{\text {th }}$ June (Table 2) due to earlier earthed crops lead to higher yields of cane. However, net returns and B: C ratios of $25^{\text {th }}$ May and $25^{\text {th }}$ June earthed crops did not vary much as the variations in the yields obtained under late earthed crops of May and June were not much. Higher net return and B: C ratios were also fetched with $20 \mathrm{~cm}$ height of earthed up crops as compared to late earthed crops because of higher cane yields and stover yields. The response of nitrogen rates helped in increasing the net monetary returns and continued to increased it by $(31.76,47.52 \%)$ and $\mathrm{B}$ : $\mathrm{C}$ ratio $(19.11 \%)$ and $22.96 \%)$ up to the highest $\mathrm{N}$ dose tested in the study $(210 \mathrm{~kg} / \mathrm{ha}$ ). The B: C ratio also increased significantly up to $210 \mathrm{~kg} \mathrm{~N} / \mathrm{ha}$. Higher economic returns (Rs 326393/ha) with B: C (3.60) ratio was obtained at higher N doses because higher nitrogen levels increased the number of millable canes, fresh weights, dry matter contents, cane yields and stover yields. These results are in conformity with the findings of Singh et al. (2007). The study also demonstrated that the profitability of net monetary returns (Rs $265707 / \mathrm{ha}$ ) was fetched from $20 \mathrm{~cm}$ height of earthed up as compared to $10 \mathrm{~cm}$ earthed up crop during both the ratoon crops of sugarcane. Across the time of earthing up ( $25^{\text {th }}$ April), level of earthing up (20 cm height of earthing up) and nitrogen levels $(210 \mathrm{~kg} \mathrm{~N} / \mathrm{ha})$ produced higher net monetary returns with $\mathrm{B}$ : $\mathrm{C}$ ratios in both the ratoon crops.

By and large sugarcane crop in tropics and sub-tropics is ratooned at least once and more number of ratoon crops could be taken under well managed package and practices with advanced technology. This practice has enabled 
the farmers and mill owners to plant once and harvesting thrice to make sugarcane cultivation more profitable. Considering the importance of ratoon crops in sugarcane cultivation it was concluded that both first and second ratoon crops raised from a single plant cane proved beneficial for farmers when earlier earthing at $25^{\text {th }}$ April was done with $20 \mathrm{~cm}$ height along with $210 \mathrm{~kg} \mathrm{~N}$ /ha for better yield and ratoonability of sugarcane. As it is highly responsive towards $\mathrm{K}$ fertilization, so its doses should be increased in order to maintain the $\mathrm{K}$ fertility in the soil instead of depriving it from the soil to sustain the crop production.

\section{References}

Ali, F. G., Akhtar, M., Saeed, M. \& Shahid, A. (2002). Effect of different moisture regimes and fertilizer levels on dry matter accumulation in spring sugarcane. Pakistan Sugar Journal, 17(3), 28-30.

Ashraf, M. Y., Hussain, F., Akhtar, J., Gul, A., Ross, M., \& Ebert, G. (2008). Effect of different sources and rates of nitrogen and supra optimal level of potassium fertilization on growth, yield and nutrient uptake by sugarcane grown under saline conditions. Pakistan Journal of Botany, 40(4), 1521-1531.

Choudhary, A. U., \& Ullah, Z. (2001). Determination of optimum level of nitrogen and its effects on yield and quality of ratoon sugarcane. Pakistan Journal of Biological Sciences, 4(4), 477-478. http://dx.doi.org/10.3923/pjbs.2001.477.478

Dougall, A. J., \& Halpin, N. V. (2008). The influence of depth and method of cane planting on stool tipping and yield on a red ferrosol at Bundaberg. In: Proceedings of the 2008 Conference of the Australian Society of Sugar Cane Technologists held at Townsville, Queensland, Australia, 29 April - 2 May 2008, pp 241-250.

Jackson, M. L. (1973). Soil Chemical Analysis, (2nd Indian Print) Prentice- Hall of India Pvt. Ltd. New Delhi, pp. 38-336.

Lal, M., \& Singh, A. K. (2008). Multiple ratooning for high cane productivity and sugar recovery. In: Proceedings of National Seminar on varietal planning for improving productivity and sugar recovery in sugarcane held at G.B.P.U.A. \& T. Pantnagar, 14-15 Feb. 2008, pp. $62-68$.

Lal, R., Chand, M., Khippal, A., Singh, S., \& Singh, Ran. (2008). Response of newly developed sugarcane varieties of north- west zone of India to fertility level. In: Proceedings of National Seminar on varietal planning for improving productivity and sugar recovery in Sugarcane held at G.B.P.U.A. \& T. Pantnagar, 14-15 Feb.2008, pp. 202-206.

Olsen, S. R., Cole, C. V., Watanable, F. S., \& Dean, L. S. (1954). Estimation of available phosphorus in soils by extraction with sodium bicarbonate. Circ. U. S. Dep. Agric, 939, 18.

Qadir, G., Ishtiaq, M., Sajid, M., \& Ali, I. (1998). Growth and yield of (Solanum tuberosum L.) cultivar ultimus as affected by earthing-up. Sarhad Journal of Agriculture, 14(6), 553-557.

Shukla, S. K. (2005). Productivity and economics of high-sugar genotypes of sugarcane (Saccharum officinarum hybrid complex) in plant ratoon system under various planting seasons and fertility levels. Indian Journal of Agronomy, 52(2), 164-167.

Singh, D., Saini, S. K., \& Sinha, S. K. (2008). Performance of sugarcane genotypes under different fertility levels. In: Proceedings of National Seminar on varietal planning for improving productivity and sugar recovery in Sugarcane held at G.B.P.U.A. \&T. Pantnagar, 14-15 Feb. 2008, pp. 240-241.

Singh, K. P., Suman, A., Singh, P. N., \& Lal, M. (2007). Yield and soil nutrient balance as on a sugarcane plant-ratoon system with conventional and organic nutrient management in sub-tropical India. Nutr Cycl Agroecosys, 79, 209-219. http://dx.doi.org/10.1007/s10705-007-9108-4

Subbiah, B. V., \& Asija, G. L. (1956). A rapid procedure for the estimation of available nitrogen in soils. Current Science, 25, 259-260.

Yadav, R. L., \& Shukla, S. K. (2008). Sugarcane production technology for hgher productivity. In: Proceedings of National Seminar on varietal planning for improving productivity and sugar recovery in Sugarcane held at G.B.P.U.A. \& T. Pantnagar, 14-15 Feb. 2008, pp. 207-209.

Walkley, A., \& Black, C. A. (1934). An examination of different methods for determining soil organic matter and a proposed modification of the chromic acid titration method. Soil Science, 37, 29-38. http://dx.doi.org/10.1097/00010694-193401000-00003 